TITLE:

\title{
Fair Value Accounting and Procyclicality: Accounting for Securitization
}

\author{
$\operatorname{AUTHOR(S):~}$ \\ Kusano, Masaki
}

\section{CITATION:}

Kusano, Masaki. Fair Value Accounting and Procyclicality: Accounting for Securitization. 京都大学大学院経済学研究科Working Paper 2011, 120

ISSUE DATE:

2011-01

URL:

http://hdl.handle.net/2433/141777

RIGHT: 
Fair Value Accounting and Procyclicality: Accounting for Securitization*

\author{
Masaki Kusano \\ Graduate School of Economics \\ Kyoto University \\ Yoshida-honmachi, Sakyo-ku, Kyoto, 606-8501, Japan \\ E-mail:kusano@econ.kyoto-u.ac.jp
}

January 2011

\footnotetext{
* Acknowledgements: The author gratefully appreciates the helpful comments and suggestions received from the seminar participants at the Research Institute for Economics and Business Administration - Kobe University and Université Paris-Dauphine. He also appreciates the participants of 22nd Asian-Pacific Conference on International Accounting Issues at Gold Coast. He gratefully acknowledges the financial support from the Zengin Foundation for Studies on Economics and Finance.
} 


\title{
Fair Value Accounting and Procyclicality: Accounting for Securitization
}

\begin{abstract}
The recent financial crisis has lead to heated debates on the pros and cons of fair value accounting from the perspectives of illiquidity and procyclicality. Previous research investigates the relationship between fair value accounting and procyclicality and finds mixed evidence of this relationship during economic recessions.

However, few studies examined the relationship between fair value accounting and the financial crisis during economic booms. The purpose of this study is to examine whether fair value accounting promotes procyclicality by focusing on securitization transactions during economic booms.

We examine the relationship between securitization accounting and procyclicality by using a parsimonious model. The findings are as follows. When a gain on sale is recognized under certain conditions, sale accounting decreases the leverage ratio compared with that before the securitization transaction. Banks increase assets to maintain the target leverage ratio. Furthermore, if banks conduct securitization transactions and adopt sale accounting, the leverage ratio decreases; therefore, banks increase assets to maintain the leverage ratio. It is expected that both sale accounting and fair value accounting promote procyclicality during economic booms.

This study makes two contributions to accounting literature and accounting standard settings. First, it proposes a new perspective on the relationship between fair value accounting and procyclicality. Second, this study suggests that accounting standard setters reconsider the movement of accounting for securitization.
\end{abstract}

Keywords: Fair Value Accounting, Procyclicality, Securitization Transactions, Sale Accounting 


\section{Introduction}

Currently, the U.S. Financial Accounting Standards Board (FASB) and the International Accounting Standards Board (IASB) consider fair value as a possible measurement basis in many situations and have moved ahead with the convergence of accounting standards (Barth, 2007). For instance, take accounting for financial instruments. The IASB and the FASB have set long-term objectives, one of which is to require all financial instruments to be measured at fair value, and to recognize realized and unrealized gains and losses as income in the period in which they occur (IASB, 2005). They have also discussed the adoption of full fair value accounting (IASB, 2008).

In the U.S., when interest rates increased and residential prices dropped, subprime loan defaults increased. Subprime mortgage banks stopped originating subprime mortgages and filed for bankruptcy ${ }^{1}$. In July 2007, credit rating agencies downgraded the credit rates of subprime mortgage-backed securities (MBSs). The European and U.S. financial institutions with significant asset-backed securities, such as subprime MBSs and related collateralized debt obligations (CDOs), announced huge losses. Thus, credit crunch began and continued during 2007-2008 (Ryan, 2008b).

The financial crisis arising from the securitization of subprime loans influenced the trends in full fair value accounting for financial instruments that has been promoted by the IASB and the FASB. For example, the Financial Stability Forum (FSF) recommends that the standard setters consider enhancing the accounting model so that the use of fair value accounting is carefully examined for financial instruments of credit intermediaries (FSF, 2009). Moreover, the Financial Crisis Advisory Board (FCAG) states that simplified mixed attribute accounting rather than full fair value accounting is preferable (FCAG, 2009, p. 5).

The recent financial crisis has lead to heated debates on the pros and cons of fair

${ }^{1}$ For example, New Century Financial, the second largest subprime mortgage originator in 2006, stopped originating subprime mortgages and filed for bankruptcy on April 2, 2007. 
value accounting (Laux and Leuz, 2009; Magnan, 2009). There are two opposing views on the relationship between fair value accounting and the financial crisis. One is that fair value accounting played a substantial role in the financial crisis. It is criticized as having triggered a liquidity death spiral and is blamed for the crisis (American Bankers Association, 2008; Wallison, 2008). The other is that fair value accounting did not play a substantial role in the financial crisis (Barth and Landsman 2010; Laux and Leuz, 2010; Ryan, 2008a; SEC, 2008). Rather, fair value (market price) is only linked to capital regulations and private contracts (e.g., collateral and margin requirements, haircuts), and therefore, fair value accounting does not cause the financial crisis (Ball, 2008; Véron, 2008).

Recently, studies on the relationship between fair value accounting and procyclicality have been conducted. Analytical research demonstrates that pure fair value accounting contributes to procyclicality in illiquid markets as compared with pure historical cost accounting (Allen and Garletti, 2008; Cifuentes et al., 2005; Heaton et al., 2010; Plantin et al., 2008a). However, current accounting standards measure some assets at historical cost and other assets at fair value. Even though analytical models show that pure fair value accounting contributes to procyclicality, it is not clear whether there exists a relationship between fair value accounting and procyclicality. Focusing on the impairment of asset-backed securities during economic recessions, empirical studies investigated the relationship between fair value accounting and procyclicality and found mixed evidence of this relationship (e.g., Badertscher et al., 2010; Bhat et al., 2010; Shaffer, 2010).

Few studies examined the relationship between fair value accounting and the financial crisis during economic booms ${ }^{2}$. Currently, banks do not hold loans until maturity and adopt an originate-and-distribute model that transfers loans for securitization. Banks use two accounting treatments for securitization transactions; the

2 Bryan et al. (2010) is an exception, and they investigated whether fair value accounting promoted procyclicality before the financial crisis. 
sale accounting approach and the secured borrowing accounting approach. Almost all banks use sale accounting for securitization transactions and report gains on sales. Fair value measurements of retained interests and recourse obligations affect the amount of the gain on sale. In some cases, a gain on sale is offset by losses after securitization. Gains on sale as well as unrealized income under fair value accounting have large uncertainties. Thus, we can analyze the relationship between fair value accounting and procyclicality by focusing on accounting for securitization. This study investigates and demonstrates this relationship during economic booms.

This study makes two contributions to accounting literature and accounting standard settings. First, it proposes a new perspective on the relationship between fair value accounting and procyclicality. As described above, previous literature focused on the impairment of asset-backed securities during economic recessions and examined the relationship between fair value accounting and procyclicality. On the other hand, this study focuses on economic booms in which the cause of financial crisis was present. We investigate and show the relationship between fair value accounting and procyclicality from the perspective of accounting for securitization.

Second, this study suggests that accounting standard setters reconsider the movement of accounting for securitization. The U.S. accounting standards adopted the financial component approach for transfer of financial assets (SFAS140; SFAS166). This approach assumes that financial assets are decomposed into components and that the measurement of each component is reliable. However, in securitization transactions, where the underlying assets are subprime mortgages, this assumption is not always satisfied. In this case, fair value measurement creates the potential for either an unintentional or an intentional bias.

The remainder of the paper proceeds as follows. Section 2 reviews the concept of procyclicality and considers the relationship between fair value accounting and procyclicality. Section 3 reviews previous studies that examine this relationship by focusing on the impairment of asset-backed securities during economic recessions. 
Section 4 investigates whether fair value accounting promotes procyclicality from the perspective of accounting for securitization during economic booms. Section 5 provides summaries and concluding remarks.

\section{Procyclicality}

The relationship between fair value accounting and procyclicality has been discussed for a long time. Full fair value accounting for financial instruments has been proposed for more than ten years (FASB, 1999; IASC/CICA, 1997; JWGSS, 1999; JWGSS, 2000), but has faced opposition. In particular, the banking regulatory and supervisory bodies (central bank) have strongly opposed this proposal from the point of view of financial stability (procyclicality) (BIS, 2001; ECB, 2001; ECB, 2004; ECB, 2006; Enria et al., 2004). This section reviews the concept of procyclicality and considers the relationship between fair value accounting and procyclicality.

\subsection{Concept of Procyclicality}

The development of financial systems has reinforced the momentum of underlying business cycles, and in some cases has led to extreme swings in business activities (Borio et al., 2001, p. 1). These experiences show that the dynamic interactions (positive feedback mechanisms) between the financial and the real sectors of the economy amplify business fluctuations and possibly cause or exacerbate financial instability. Such feedback mechanisms appear during economic downturns or when the financial system is strained (BIS, 2008, p. 1; FSF, 2009, p. 8).

When banks report losses and decrease in capital, they must restrict further lending and/or sell assets that they hold to control capital ratios (leverage ratios); such retrenchment weakens economic activities. In addition, because banks are extremely careful in assessing the risk of default when determining their interest in firms after a major financial crisis and the related bankruptcies of firms, credit risk becomes overvalued during economic recessions. Thus, financial systems act as shock amplifiers 
rather than playing their usual shock absorber role.

Severe financial sector distress is preceded by unusually strong credit and growth in asset prices, as well as prolonged periods of unusually low risk premiums. During economic booms, firms usually report good performance and therefore, their credit risk would decrease and borrowing capabilities from banks would grow. During such times, it is possible for firms to increase production capacity through debt financing. In addition, during economic booms, banks' risk appetite increases and external financing constraints are eased, which facilitates risk taking. Consequently, banks are likely to overestimate the creditworthiness of borrowers, and these optimistic risk assessments prompt further growth in credit.

Therefore, as banks' lending activities are by nature procyclical, the procyclicality of banks' credit is already observed under historical cost accounting (Boyer, 2007, p. 791). However, compared with historical cost accounting, fair value accounting is expected to increase procyclicality by making valuations more sensitive to economic cycles (BIS, 2008, p. 3). In the following subsection, we consider and discuss the relationship between fair value accounting and procyclicality to determine the reason why fair value accounting promotes procyclicality compared with historical cost accounting.

\subsection{Fair Value Accounting and Procyclicality}

We examine the relationship between fair value accounting and procyclicality by using a parsimonious model.

Denote the value of assets by $A$ and the value of debt by $D$, then $A-D$ is the value of equities $(A>D>0)$. If an investment succeeds, banks can improve their return on equity (ROE) by holding more assets than equities. On the other hand, if an investment fails, the profitability of banks decreases. Thus, we can treat leverage ratios as risk measures for evaluating banks' operating and financial risk. This study simply

uses the leverage ratio $L$, which is $\frac{A}{A-D}$, as a measure of risk. Moreover, we compute 
$\frac{\partial L}{\partial A}$ by treating $D$ as a constant, and write it as:

$$
\frac{\partial L}{\partial A}=\frac{-D}{(A-D)^{2}}<0
$$

If $A$ increases and $D$ is held constant, $L$ will decrease. Therefore, leverage is inversely related to the value of assets. Adrian and Shin (2010) show that for U.S. commercial banks, the relationship between changes in assets and changes in leverage ratio tends to be fixed, and there is a strong positive relationship between changes in assets and changes in leverage ratio for U.S. investment banks. This implies that U.S. commercial banks and investment banks raise finances using debt and purchase assets to manage their leverage ratios for changes in assets.

Then, we investigate whether fair value measurement of assets have an effect on procyclicality compared with historical cost measurement. In the case of historical cost measurements, the leverage ratio is written as:

$$
L_{H}=\frac{A_{H}}{A_{H}-D_{H}},
$$

where $L_{H}$ is the leverage ratio, $A_{H}$ is value of assets and $D_{H}$ is value of debt. First, we consider that banks measure assets at fair value during economic booms. Suppose that the price of the assets increases by $\alpha A_{H}(\alpha>0)$ and the value of the assets $\left(A_{F 1}\right)$ is $(1+\alpha) A_{H}$. In the case of fair value measurement during economic booms, the leverage ratio is written as:

$$
L_{F 1}=\frac{A_{F 1}}{A_{F 1}-D_{H}}=\frac{A_{H}}{A_{H}-\left(\frac{1}{1+\alpha}\right) D_{H}},
$$

where $L_{F 1}$ is the leverage ratio. When comparing $L_{F 1}$ with $L_{H}, L_{F 1}$ is smaller than $L_{H}$ through the following relationship:

$$
L_{F 1}=\frac{A_{H}}{A_{H}-\left(\frac{1}{1+\alpha}\right) D_{H}}<\frac{A_{H}}{A_{H}-D_{H}}=L_{H} .
$$


Thus, if banks maintain a constant (or increasing) leverage ratio for a given change in assets, they must finance using debt if they are to maintain the target leverage ratio. Suppose that banks maintain the same leverage ratio that is measured using historical costs. Banks must then take additional debt of $B$ to purchase assets valued at $B$. Denote the adjusted leverage ratio by $L_{F 1}^{*}$ and we obtain this equality:

$$
L_{F 1}^{*}=\frac{(1+\alpha) A_{H}+B}{(1+\alpha) A_{H}+B-\left(D_{H}+B\right)}=\frac{A_{H}}{A_{H}-D_{H}}=L_{H} .
$$

Therefore, the solution is as follows:

$$
B=\frac{\alpha A_{H} D_{H}}{A_{H}-D_{H}}=\alpha D_{H} L_{H} .
$$

Banks will take additional debt to maintain the same leverage ratio that was measured using historical costs. If banks have higher leverage ratios, they must increase their amounts of debt and assets, because $B$ is positively correlated with $L_{H}$. When executive compensation is linked to ROE, bank executives have incentives to increase the leverage ratio during economic booms because the relationship between changes in ROE and changes in the leverage ratio tends to be positive during such periods. In this manner, if banks measure assets at fair value, banks will increase both assets and debt to maintain their target leverage ratio.

Next, we examine whether banks measure assets at fair value during economic recessions. Suppose that asset prices decreases by $-\beta A_{H}(0<\beta<1)$ and the value of assets $\left(A_{F 2}\right)$ is $(1-\beta) A_{H}$. In the case of fair value measurement during economic recessions, the leverage ratio is written as:

$$
L_{F 2}=\frac{A_{F 2}}{A_{F 2}-D_{H}}=\frac{A_{H}}{A_{H}-\left(\frac{1}{1-\beta}\right) D_{H}},
$$

where $L_{F 2}$ is the leverage ratio. When comparing $L_{F 2}$ with $L_{H}, L_{F 2}$ is larger than 
$L_{H}$ through the following relationship:

$$
L_{F 2}=\frac{A_{H}}{A_{H}-\left(\frac{1}{1-\beta}\right) D_{H}}>\frac{A_{H}}{A_{H}-D_{H}}=L_{H} .
$$

Thus, if banks maintain a constant (or decreasing) leverage ratio for given changes in asset value, banks must raise equity or decrease both assets and debt to maintain this leverage ratio. If banks find it difficult to take the former option, they must choose the latter option. Suppose that banks sell $C$ worth of assets and pay off $C$ worth of debt to maintain the same leverage ratio as measured at historical costs. This amount is written as follows:

$$
C=\frac{\beta A_{H} D_{H}}{A_{H}-D_{H}}=\beta D_{H} L_{H} .
$$

If banks have higher leverage ratios, they must decrease the amounts of assets and debt, because $C$ is positively correlated with $L_{H}$. To restrict the leverage ratio or VaR (Value-at-Risk), bank executives have the incentive to sell assets and decrease debt (Shin, 2010). In this manner, if banks measure assets at fair value, banks will decrease both assets and debt to maintain their leverage ratio.

Accordingly, when we assume that banks maintain a constant (or positively related) leverage ratio as asset prices change, fair value accounting implies that asset and debt values increase or decrease compared with historical cost accounting: fair value accounting promotes procyclicality through the "accounting accelerator effect" (Boyer, 2007, p. 780). If financial markets are not perfectly liquid so that greater demand for assets increases their prices, fair value measurements decrease the leverage ratio. Banks increase their assets to maintain their leverage ratio. Therefore, as greater demand for assets puts pressure on their prices, assets are increased to maintain the target leverage ratio under fair value measurements. On the other hand, during an economic recession, we observe inverse relationships (Plantin et al., 2008b). 


\section{Impairment and Procyclicality: Literature Review}

Suppose we assume that banks manage the leverage ratio. Then the fair value measurement of assets contributes to procyclicality compared with historical cost measurements. In particular, if financial markets are not perfectly liquid to ensure that a greater supply of assets reduces their prices, banks will sell assets to maintain or decrease the leverage ratio; this reduces asset prices, and thus banks decrease their asset holdings (Allen and Garletti, 2008; Cifuentes et al., 2005; Heaton et al., 2010). Banks can also sell relatively illiquid assets to preempt the anticipated sales made by other market participants when bank executives focus on short-term earnings for executive compensation (Plantin et al., 2008a).

Analytical research demonstrates that pure fair value accounting contributes to procyclicality in illiquid markets as compared with pure historical cost accounting. However, existing accounting standards measure some assets at historical cost and other assets at fair value. Neither pure historical cost accounting nor pure fair value accounting has been adopted. In fact, for the U.S. banks, loans and leases held for investment that apply historical cost accounting comprise half or more of their total assets (Laux and Leuz, 2010; SEC, 2008). Even though theoretical models show that pure fair value accounting promotes procyclicality, it is not clear that the relationship between fair value accounting and procyclicality is actually observed.

When the fair value of asset-backed securities was below its cost basis and this decline was judged to be other-than-temporary impairment, the carrying amounts of these securities were written down to fair value and impairment losses were recognized in earnings ${ }^{3}$. With regard to procyclicality, impairment of asset-backed securities is

\footnotetext{
3 The FASB amends accounting for impairment of financial assets to mitigate the effects of financial crisis. In April 2009, the FASB issued FASB Staff Position, No. FAS115-2 and FAS 124-2, Recognition and Presentation of Other-Than-Temporary Impairments, and required that other-than-temporary impairment is separated into credit loss and other factors and be recognized in earnings for the former and in other comprehensive income
} 
expected to have the same effect as fair value accounting. Thus, prior empirical research examines the relationship between fair value accounting and procyclicality by focusing on impairment.

Shaffer (2010) analyzes the relationship between fair value accounting and procyclicality using a sample of 14 large bank holding companies in 2008. The analysis verifies that other-than-temporary impairments of available-for-sale and held-to-maturity securities have quite small effects on regulatory capital (Tier 1), and the evidence of procyclical behavior, such as the fire-sale of assets, was not found. Shaffer (2010) shows that for many banks, loan loss provisions have larger effects on regulatory capital than other-than-temporary impairments ${ }^{4}$.

Badertscher et al. (2010) investigated whether fair value accounting promotes procyclicality by using a sample of 150 bank holding companies. The industry-level analyses found that although other-than-temporary impairments of available-for-sale and held-to-maturity securities increased during the financial crisis (2007-2008), other-than-temporary impairments had minimal impact on regulatory capital (Tier 1) compared with loan loss provisions. Sales of available-for-sale and held-to-maturity securities during the financial crisis were in line with levels seen before the crisis (2004-2006): Badertscher et al. (2010) found no evidence of banks' fire-sale of assets during the crisis. On the other hand, firm-level analyses showed that sales of securities were significantly correlated with the amount of other-than-temporary impairments and with decrease in capital ratios. This result suggests a relationship between fair value accounting and procyclicality. However, as other analyses found no evidence of procyclical behavior such as fire-sale of assets, Badertscher et al. (2010) concluded that fair value accounting does not contribute to procyclicality.

While Shaffer (2010) and Badertscher et al. (2010) focused on the relationship for the latter (FASB, 2009b, pars. 29-30). 4 SEC (2008) examined the cause of failure of 50 failed banks during 2008. The result showed that even though the failed banks reported larger amounts of fair value losses, the failure was due to loan losses rather than fair value losses. 
between fair value losses and sales of securities, Bhat et al. (2010) investigated whether fair value accounting causes procyclicality by focusing on the relationship between sales of securities and changes in the prices of securities. The analyses found a relationship between decreases in liquidity of nonagency MBSs and sales of nonagency MBSs. In particular, the results showed that the relationship was more significant for banks with greater nonagency MBSs holdings, greater nonperforming loans, and lower capital ratios. Furthermore, Bhat et al. (2010) found reduced procyclical behavior after a change in accounting rules for impairments; that is, the easing of the fair value accounting rule ${ }^{5}$. These findings suggest a relationship between fair value accounting and procyclicality.

In summary, analytical research demonstrates that pure fair value accounting contributes to procyclicality in illiquid markets. However, current accounting standards adopt mixed attribute accounting. Focusing on the impairment of securitized instruments during economic recessions, previous empirical research investigated whether fair value accounting causes procyclicality and has found mixed evidence ${ }^{6}$.

\section{Accounting for Securitization and Procyclicality}

Even though the cause of financial crisis was present during economic booms that precede economic downturns, very few studies examined the relationship between fair

5 In addition, Bhat et al. (2010) found higher abnormal stock returns on event dates related to the easing of fair value accounting rules for banks with greater nonagency MBSs holdings and greater nonperforming loans. Further, Bowen et al. (2010) investigate whether bank stock prices are affected by events related to relaxing (or retaining) fair value accounting or impairment rules during the financial crisis. They generally provided evidence that relaxing (retaining) fair value accounting or impairment rules produced positive (negative) abnormal returns on event dates.

6 Khan (2009) investigated whether fair value accounting was associated with an increase in systemic risk in the network of banks. The analysis found that more fair-value oriented banks experienced negative returns when money-center banks performed poorly. Moreover, the result showed that fair value accounting was associated with an increase in systemic risk during periods of market illiquidity. Furthermore, Khan (2009) found that banks with lower capital ratios or relatively higher proportions of fair value assets and liabilities affected the increase in systemic risk associated with fair value accounting. 
value accounting and procyclicality before the financial crisis. Considering the recent financial crisis that arose from the securitization of subprime loans, this section investigates whether accounting for securitization promotes procyclicality ${ }^{7}$.

\subsection{Accounting for Securitization}

Currently, banks do not hold loans until maturity; instead, they have adopted an originate-and-distribute model that transfers loans for securitization. Shipper and Yohn (2007) describe the reasons why banks conduct asset securitizations; they do so to diversify holding assets, obtain greater liquidity for future growth, and to reduce financing costs.

There are two accounting treatments that firms use to account for securitization transactions. One approach is sale accounting, which treats asset transfers as financial asset sales. The other approach is secured borrowing accounting, which treats asset transfers as borrowings by pledging financial assets. Under sale accounting, transferors remove the financial assets from the balance sheet and report gains or losses, which are calculated as the difference between the sale proceeds and the book value of the financial assets sold in the income statement. On the other hand, under secured borrowing accounting, financial assets remain on the balance sheet and transferors recognize the proceeds as liabilities.

Although securitization accounting is classified as sale accounting or secured borrowing accounting, neither accounting treatment could faithfully represent many securitization transactions. Because transferors (originators) face numerous risks for transferred assets in many securitization transactions, it is difficult to classify

7 Asset securitization is a financing method that transfers financial assets (homogenous loans such as mortgages, automobile loans, and credit card loans) from transferors (originators) to special purpose entities (SPEs) and issues securities that back the cash flows from the financial assets. This securitization process clarifies that securitization transactions are related to the following two accounting treatments: accounting for transfers of financial assets and accounting for consolidation of SPEs. This study focuses on accounting for transfers of financial assets and uses the term "accounting for securitization." 
securitization transactions as either sale or secured borrowing.

In many securitization transactions, transferors (originators) hold retained interests and recourse obligations for credit enhancement. For credit enhancement, it is possible to issue high credit-rated asset-backed securities and to prevent special purpose entities (SPEs) from becoming bankrupt. Holders who have retained interests have the right to receive cash flows only after all payments of principal and interest for senior interests have been made, and thus have to bear losses for not collecting cash flows at the beginning. Moreover, holders with recourse obligations must buy back transferred assets when certain events such as defaults occur. Thus, transferors (originators) retain numerous risks for transferred assets by holding retained interests and recourse obligations for credit enhancement. Characteristics of transferred assets determine the extent to which transferors (originators) retain risks for transferred assets (Chen et al., 2008).

Statement of Financial Accounting Standards (SFAS) 140, Accounting for Transfers and Servicing of Financial Assets and Extinguishments of Liabilities, distinguishes between sale accounting and secured borrowing accounting, whether or not control over transferred assets is surrendered ${ }^{8,9}$. That is, if control is surrendered, firms can account for securitization transactions using sale accounting and vice versa (SFAS140, pars. 11-12). Under SFAS140, firms can use sale accounting for securitization transactions if control over transferred assets is surrendered, even though they retain large portions of the risks ${ }^{10}$.

8 SFAS140 considers that control over transferred assets is surrendered if all of the following three conditions are met: (1) the transferred assets have been isolated from a transferor; (2) a transferee has the right to pledge or exchange the received assets; and (3) the transferor does not maintain effective control over the transferred assets (SFAS140, par. 9).

9 In June 2010, the FASB issued SFAS166, Accounting for Transfers of Financial Assets, and amended SFAS140. This section examines the relationship between accounting treatments before the crisis and procyclicality; thus, we use original rules.

10 This is also true for International Accounting Standard (IAS) 39, Financial Instruments: Recognition and Measurement. However, the basic approach for treating transfers of financial assets (derecognition) is different in SFAS140 and IAS39. For more 
In addition to economic motivations, banks conduct securitization transactions for the purpose of accounting motivations, such as decreasing the capital ratio (Minton et al., 2004) and earnings management (Karaoglu, 2005; Dechow and Shakespeare, 2009; Dechow et al., 2010). Compared with secured borrowing accounting, sale accounting reduces reported debt and raises reported net income when a gain on sale is recognized. Certainly, sale accounting has accounting benefits. Therefore, almost all firms structure securitization transactions to meet the requirements of sale accounting and report gains on sale (Dechow, et al., 2010, p. 5; Barth and Landsman, 2010, p. 409).

Suppose transferors apply sale accounting and hold retained interests and recourse obligations. If low-risk assets are transferred, transferors are not expected to report impairments of retained interests and provide recourse. In this case, the possibility that gains on sales can be offset by losses after securitization is relatively low. However, if risky assets such as subprime mortgages are transferred, transferors are expected to report impairments of retained interests and provide recourse. Thus, the possibility is relatively high that gains on sales can be offset by losses after securitization.

Although gains on sales are calculated as the differences between the sale proceeds and the book value of transferred assets, fair value measurements of retained interests and recourse obligations have effects on the amounts of the gain on sale. It is possible for transferors to record larger gains on sale by overestimating the fair value measurement of retained interests and/or by underestimating the fair value measurement of recourse obligations. Because retained interests and recourse obligations that transferors hold are traded only occasionally, transferors must estimate fair value using internal valuation models. Accordingly, the accuracy of a transferor's reported gain on sale depends on its ability to estimate the fair value of retained interests and recourse obligations (Ryan, 2007, pp. 218-219).

Transferors provide non-contractual (implicit) recourses as well as contractual details on these differences, see Adhikari and Betrancourt (2008) and Schipper and Yohn (2007). 
(explicit) recourses. Transferors buy back transferred assets to absorb losses from transferred assets to protect their reputations ${ }^{11}$. Implicit recourses require cash outflows in certain events. But the amount and timing of the cash outflows are not specified. Therefore, it is not clear whether implicit recourses meet the current definitions of liability in conceptual frameworks or are treated as constructive obligations (Shipper and Yohn, 2007, p. 75). Because implicit recourses are not recognized as liabilities on the balance sheet, gains on sales would be offset by losses on recourse in the event that implicit recourses are provided.

In summary, banks use two accounting treatments to account for securitization transactions: sale accounting and secured borrowing accounting. Sale accounting has accounting benefits compared with secured borrowing accounting. Even though transferors hold numerous risks for transferred assets through not only retained interests and recourse obligations but also from implicit recourse, they can adopt sale accounting. Because gains on sales are expected to be offset by losses after securitization, investigating whether gains on sales are treated as realized income is necessary in the case of transferring risky assets such as subprime mortgages ${ }^{12}$.

\subsection{Accounting for Securitization and Procyclicality}

Fair value measurement of retained interests and recourse obligations affect the magnitude of the gain on sale. As described above, in some cases gains on sales are offset by losses after securitization; thus, gains on sales carry with them large uncertainty. Therefore, sale accounting is expected to promote procyclicality during economic booms in the same way as fair value accounting.

11 If retained interests cover most potential losses from transferred assets, it is not necessary for transferors to provide implicit recourse. For instance, Amiram et al. (2010) suggest that impairments of retained interests contain information on implicit recourses. 12 Whether or not a gain on sale is treated as realized income is related to the nature of securitization transactions. Niu and Richardson (2006) show that credit rating analysts view many securitization transactions as secured borrowing. Landsman et al. (2008) find that the stock market treats securitized assets and liabilities held by SPEs as assets and liabilities of transferors. 
Under sale accounting, transferors derecognize transferred assets and recognize all assets obtained and liabilities incurred in consideration as proceeds of sales, and recognize in earnings the difference between sale proceeds and the carry amounts of transferred assets as gains or losses on the sale (SFAS140, par. 11). The assets and liabilities, except for retained interests (e.g., cash, service assets and liabilities, and recourse obligations), are measured at fair value. Retained interests such as subordinated and residual interests are measured at relative fair value ${ }^{13}$. Because SFAS140 requires firms to classify retained interests as trading or available-for-sale securities (SFAS140, par. 14), the difference between relative fair value and the fair value of retained interests is measured immediately and recognized in earnings for trading securities or in other comprehensive income for available-for-sale securities under SFAS115, Accounting for Certain Investments in Debt and Equity Securities.

\section{[Example]}

A transferor (an originator) who holds total asset $(A)$ and total liability $(D)$ transfers a financial asset (the book value: $l$ ) to an SPE. The SPE issues two types of interests: senior interests $(a)$ and subordinated interests $(r)$. The transferor obtains cash $(c)$, service assets $(s)$, and subordinated interests (retained interests), and incurs recourse obligations $(o)$. Suppose that the fair value of senior interests and the amounts of cash that the transferor accepts are same.

We examine the relationship between securitization accounting (sale accounting) and procyclicality by using a parsimonious model. The leverage ratio before a securitization transaction is $\frac{A}{A-D}$. When a transferor (an originator) adopts sale accounting for securitization transaction, the leverage ratio $\left(L_{s a}\right)$ is written as:

$$
L_{s a}=\frac{A+c+s+r-l}{A-D+c+s+r-l-o} .
$$

13 Relative fair value for retained interests is computed by multiplying the carrying amount of a transferred financial asset by the percentage of the fair value of the asset attributable to the retained interests. 
When we assume that the gain on sale is recognized $(c+s-o>l-r>0)$, the amount of the gain on sale is $(c+s-o)\left(1-\frac{l}{c+s-o+r}\right)$. In this case, $L_{s a}<L$ is satisfied under the following condition:

$$
\frac{A}{A-D}>\frac{c+s+r-l}{c+s+r-l-o} .
$$

Therefore, when a gain on sale is recognized and this condition is met, sale accounting decreases the leverage ratio compared with that before the securitization transaction. During economic booms, debtors of underlying assets are expected not to default and transferors (originators) receive principal and interest. The fair value of retained interests would be relatively overestimated and/or the fair value of recourse obligations would be relatively underestimated. The possibility of meeting the above condition would be high.

As described in section 2, we assume that banks manage the leverage ratio. If sale accounting decreases the leverage ratio, banks have incentives to increase assets and debt to maintain the target leverage ratio. Suppose that banks take an additional debt of $E$ to purchase $E$ worth of assets to maintain the same leverage ratio as before the securitization transactions. $E$ is written as:

$$
E=\frac{(\delta D-o) A}{A-D}=(\delta D-o) L,
$$

where $\delta=\frac{c+s+r-l}{A}$ and $L$ is the leverage ratio before the securitization transactions. This implies that banks must increase their debt and assets if they have higher leverage ratios.

Fair value measurement of retained interests and recourse obligations has effects on the leverage ratio as well as on the amount of the gain on sale ${ }^{14}$. When we compute $\frac{\partial L_{s a}}{\partial r}$

\footnotetext{
14 For the amount of the gain on sale $(I)$, when we compute $\frac{\partial I}{\partial r}$ and $\frac{\partial I}{\partial o}$, they are written as:
} 
and $\frac{\partial L_{s a}}{\partial o}$, they are written as:

$$
\begin{gathered}
\frac{\partial L_{s a}}{\partial r}=\frac{-(D+o)}{(A-D+c+s+r-l-o)^{2}}<0, \\
\frac{\partial L_{s a}}{\partial o}=\frac{A+c+s+r-l}{(A-D+c+s+r-l-o)^{2}}>0 .
\end{gathered}
$$

Therefore, if $r$ increases and other components are held constant, $L_{s a}$ will decrease.

Also, if $O$ decreases and other components are held constant, $L_{s a}$ will decrease.

In addition, measuring retained interests and recourse obligations at fair value is expected to create the potential for either an unintentional or an intentional bias. Because retained interests and recourse obligations that transferors hold are traded only occasionally, transferors must estimate fair value using internal valuation models. In securitization transactions where the underlying assets are subprime mortgages, the probability of default is relatively high for subprime MBSs. However, credit risks of the debtors are underestimated to reflect favorable economic conditions. By overestimating retained interests and/or underestimating recourse obligations, the probability of measuring smaller leverage ratios would be high. In this case, banks must increase assets and debt to manage the leverage ratio.

In summary, when gains on sales are recognized and certain conditions are met, sale accounting reduces the leverage ratio compared with holding financial assets. In addition, when banks adopt sale accounting for securitization transactions during economic booms, the leverage ratio decreases as retained interests and recourse obligations are measured at fair value. In this manner, sale accounting decreases the leverage ratio, and then

$$
\begin{gathered}
\frac{\partial I}{\partial r}=\frac{(c+s-o) l}{(c+s-o+r)^{2}}>0, \\
\frac{\partial I}{\partial o}=-\left\{1-\frac{l r}{(c+s-o+r)^{2}}\right\}<0 .
\end{gathered}
$$

Thus, if $r$ increases and other components are held constant, $I$ will increase. Also, if $o$ decreases and other components are held constant, $I$ will increase. 
banks must increase their assets to maintain the target leverage ratio. Moreover, if banks conduct securitization transactions and adopt sale accounting, then the leverage ratio decreases and assets are increased to maintain the target leverage ratio. Both sale accounting and fair value accounting are expected to promote procyclicality through the accounting acceleration effect during economic booms.

\section{Concluding Remarks}

We consider whether fair value accounting promotes procyclicality and find the relationship between fair value accounting and procyclicality by focusing on securitization transactions during economic booms. There are two accounting treatments for securitization transactions: sale accounting and secured borrowing accounting. Sale accounting has accounting benefits compared with secured borrowing accounting; almost all banks structure securitization transactions to meet the requirements for sale accounting. Even though transferors hold numerous risks for transferred assets through retained interests and recourse obligations, as well as implicit recourses, they can adopt sale accounting. In the case of transferring risky assets such as subprime mortgages, it is expected that gains on sales are offset by the impairments of retained interests and losses of explicit or implicit recourses after securitization.

When gains on sales are recognized and certain conditions are met, sale accounting decreases the leverage ratio compared with that before the securitization transaction. The leverage ratio is smaller as retained interests and recourse obligations are measured at fair value, and then banks increase assets to maintain the target leverage ratio. Moreover, if banks conduct securitization transactions and adopt sale accounting, the leverage ratio decreases; therefore, assets are increased to maintain the target leverage ratio. It is expected that both sale accounting and fair value accounting promote procyclicality during economic booms.

An issue remains for future research. This study theoretically indicates the relationship between fair value accounting and procyclicality by focusing on 
securitization transactions. It is necessary to investigate whether this relationship is observed in reality by empirical research. 


\section{References}

Adhikari, A. and L. Betancourt (2008), "Accounting for Securitizations: A Comparison of SFAS 140 and IASB 39," Journal of International Financial Management and Accounting; Vol. 19, Issue 1, pp. 73-105.

Adrian, T. and H. S. Shin (2010), "Liquidity and Leverage," Journal of Financial Intermediation, Vol. 19, Issue 3, pp. 418-437.

Allen, F. and E. Carletti (2008), "Mark-to-Market Accounting and Liquidity Pricing," Journal of Accounting and Economics, Vol. 45, Issues 2-3, pp. 358-378.

American Bankers Association (2008), "Re: File Number 4-573-SEC Study of Mark to Market Accounting,” November 13.

Amiram, D., W. R. Landsman, K. Peasnell and C. Shakespeare (2010), "Market Reaction to Securitization Retained Interest Impairments during the Financial Crisis of 2007-2008," Working Paper.

Badertscher, B. A., J. J. Burks and P. D. Easton (2010), "A Convenient Scapegoat: Fair Value Accounting by Commercial Banks during the Financial Crisis,” Working Paper.

Ball, R. (2008), “Don't Blame the Messenger ... or Ignore the Message,” Working Paper.

Barth, M. E. (2007), "Standard-Setting Measurement Issues and the Relevance of Research," Accounting and Business Research, Vol. 37, Special Issue: International Accounting Policy Forum, pp. 7-15.

Barth, M. E. and W. R. Landsman (2010), "How did Financial Reporting Contribute to the Financial Crisis," European Accounting Review, Vol. 19, No. 3, pp. 399-423.

Bhat, G., R. Frankel and X. Martin (2010), "Panacea, Pandora's Box, or Placebo: Feedback in Bank Holdings of Mortgage-Backed Securities and Fair Value Accounting," Working Paper.

BIS (2001), Basel Committee on Banking Supervision, "Comments on Draft Standard \& Basis for Conclusions Prepared by Financial Instruments Joint Working Group of Standard Setters Issued for Public Comment by the International Accounting Standards Committee,” 30 September. 
BIS (2008), Note for the FSF Working Group on Market and Institutional Resilience, Addressing Financial System Procyclicality: A Possible Framework, BIS.

Borio, C., C. Furfine and P. Lowe (2001), "Procyclicality of the Financial System and Financial Stability: Issues and Policy Options,” BIS Papers No. 1.

Bowen, R. M., U. Khan and S. Rajgopal (2010), "The Economic Consequences of Relaxing Fair Value Accounting and Impairment Rules on Banks during the Financial Crisis of 2008-2009," Working Paper.

Boyer, R. (2007), "Assessing the Impact of Fair Value upon Financial Crises," Socio-Economic Review, Vol. 5, No. 4, pp. 779-807.

Bryan, S., S. B. Lilien and B. Sarath (2010), "Countering Opportunism in Structuring and Valuing Transactions: The Case of Securitizations," Journal of Accounting, Auditing and Finance, Vol. 25, No. 2, pp. 289-321.

Chen, W., C. Liu and S. G. Ryan (2008), "Characteristics of Securitizations that Determine Issuers' Retention of the Risks of the Securitized Assets," The Accounting Review, Vol. 83, No. 5, pp. 1181-1215.

Cifuentes R., G. Ferrucci and H. S. Shin (2005), "Liquidity Risk and Contagion,” Journal of the European Economic Association, Vol. 3, Nos. 2-3, pp. 556-566.

Dechow, P. M., L. A. Myers and C. Shakespeare (2010), "Fair Value Accounting and Gains from Asset Securitizations: A Convenient Earnings Management Tool with Compensation Side-Benefits," Journal of Accounting and Economics, Vol. 49, Issues 1-2, pp. 2-25.

Dechow, P. M. and C. Shakespeare (2009), "Do Managers Time Securitization Transactions to Obtain Accounting Benefits?," The Accounting Review, Vol. 84, No. 1, pp. 99-132.

ECB (2001), Fair Value Accounting in the Banking Sector, ECB.

ECB (2004), “The Impact of Fair Value Accounting on the European Banking Sector - A Financial Stability Perspective," Monthly Bulletin, February, pp. 69-81.

ECB (2006), Assessment of Accounting Standards from a Financial Stability Perspective, 
ECB.

Enria, A., L. Cappiello, F. Dierick, S. Grittini, A. Haralambous, A. Maddaloni, P. Molitor, F. Pires and P. Poloni (2004), "Fair Value Accounting and Financial Stability," ECB Occasional Paper Series No. 13.

FASB (1999), Preliminary Views, on Major Issues Related to Reporting Financial Instruments and Certain Related Assets and Liabilities at Fair Value, FASB.

FASB (2009), FASB Staff Position, No. FAS115-2 and FAS124-2, Recognition and Presentation of Other-Than-Temporary Impairments, FASB.

FCAG (2009), Report of the Financial Crisis Advisory Group, FCAG.

Heaton, J. C., D. Lucas and R. L. McDonald (2010), "Is Mark-to-Market Accounting Destabilizing? Analysis and Implications for Policy, Journal of Monetary Economics, Vol. 57, No. 1, pp. 64-75.

IASB (2005), Board Decisions on International Financial Reporting Standards, IASB Update, October IASB.

IASB (2008), Discussion Paper, Reducing Complexity in Reporting Financial Instruments, IASB.

IASC/CICA (1997), Discussion Paper, Accounting for Financial Assets and Financial Liabilities, IASC.

JWGSS (1999), Financial Instruments - Issues Relating to Banks, IASC.

JWGSS (2000), An Invitation to Comment on the JWG's Draft Standard, Financial Instruments and Similar Items, JICPA.

Karaoglu, N. E. (2005), "Regulatory Capital and Earnings Management in Banks: The Case of Loan Sales and Securitizations," Working Paper.

Khan, U. (2009), "Does Fair Value Accounting Contribute to Systematic Risk in the Banking Industry?," Working Paper.

Landsman, W. R., K. V. Peasnell and C. Shakespeare (2008), “Are Asset Securitizations Sales or Loans?," The Accounting Review, Vol. 83, No. 5. pp. 1251-1272.

Laux, C. and C. Leuz (2009), “The Crisis of Fair-Value Accounting: Making Sense of the 
Recent Debate," Accounting, Organization and Society, Vol. 34, Issues 6-7, pp. 826-834.

Laux, C. and C. Leuz (2010), "Did Fair-Value Accounting Contribute to the Financial Crisis?," Journal of Economic Perspectives, Vol. 24, No. 1, pp. 93-118.

Magnan, M. L. (2009), "Fair Value Accounting and the Financial Crisis: Messenger or Contributor?," Working Paper.

Minton, B., A. Sanders and P. Strahan (2004), "Securitization by Banks and Finance

Companies: Efficient Financial Contracting and Regulatory Arbitrage," Working Paper.

Niu, F. F. and G. D. Richardson (2006), "Are Securitizations in Substance Sales or Secured Borrowing? Capital-Market Evidence," Contemporary Accounting Research, Vol. 23, No. 4, pp. 1105-1133.

Plantin, G., H. Sapra and H. S. Shin (2008a), "Marking-to-Market: Panacea or Pandora's Box," Journal of Accounting Research, Vol. 46, No. 2, pp. 435-460.

Plantin, G., H. Sapra and H. S. Shin (2008b), "Fair Value Accounting and Financial Stability," Financial Stability Review (Banque de France), No. 12, pp. 85-94.

Ryan, S. G. (2007), Financial Instruments and Institutions: Accounting and Disclosure Rules, $2^{\text {nd }}$ ed., John Wiley \& Sons, Inc..

Ryan, S. G. (2008a), Fair Value Accounting: Understanding the Issues Raised by the Credit Crunch, Council of Institutional Investors.

Ryan, S. G. (2008b), "Accounting in and for the Subprime Crisis," The Accounting Review, Vol. 83, No. 6, pp. 1605-1638.

Schipper, K. and T. L. Yohn (2007), "Standard-Setting Issues and Academic Research Related to the Accounting for Financial Asset Transfers," Accounting Horizons, Vol. 21, No. 1, pp. 59-80.

SEC (2008), Office of the Chief Accountant, Division of Corporate Finance, Report and Recommendations Pursuant to Section 133 of the Emergency Economic Stabilization Act of 2008: Study on Mark-To-Market Accounting, SEC.

Shaffer, S. (2010), "Fair Value Accounting: Villain or Innocent Victim,” Working Paper No. 
QAU 10-01, Federal Reserve Bank of Boston.

Shin, H. S. (2010), Risk and Liquidity, Oxford University Press.

Véron, N. (2008), "Fair Value Accounting is the Wrong Scapegoat for this Crisis," Accounting in Europe, Vol. 5, No. 2, pp. 63-69.

Wallison, P. J. (2008), "Fair Value Accounting: A Critique," Financial Services Outlook (American Enterprise Institute for Public Policy Research), July. 